\title{
An optical coherence tomography study for imaging the round window niche and the promontorium tympani
}

\author{
Tino Just*, Eva Lankenau, Gereon Hüttmann, Hans Pau \\ From 2nd Scientific Meeting of the Head and Neck Optical Diagnostics Society \\ San Francisco, CA, USA. 23-24 January 2010
}

Tympanosclerosis may involve the tympanic membrane, the ossicles, as well as the oval and round window niche, respectively. The surgical treatment of the obliterated oval window niche is most challenging. Beside stapesplasty, vibroplasty with coupling the floating mass transducer (FMT) onto the round window niche and into a new, so-called third window is indicated. In the latter situation, drilling a hole into the promontorium is necessary to couple the FMT close to the membranous endosteum. Any damage of the membranous inner ear needs to be avoided. The question was whether OCT is useful to identify the endosteum and to provide microanatomical information about the round window niche. OCT was carried out on human temporal bone preparations in which a third window was drilled, while leaving the membranous labyrinth and the fluid-filled inner ear intact and removing the overhang of the round window niche. A specially equipped operating microscope with integrated OCT prototype (spectral-domain-OCT) was used. The OCT images and 3D reconstructions demonstrate the usefulness of OCT to measure the drilling cavity, to visualize the inner ear structures, and to obtain microanatomical information about the round and oval window niche. These findings may have an impact on stapes surgery, on cochlea implantation, and on vibroplasty with coupling the FMT onto the round and third window. OCT-guided drilling allows identification of the intact inner ear more precisely.

Department of ORL, University of Rostock, Rostock, Germany
Published: 29 October 2010

doi:10.1186/1758-3284-2-S1-05

Cite this article as: Just et al:: An optical coherence tomography study for imaging the round window niche and the promontorium tympani. Head \& Neck Oncology 2010 2(Suppl 1):O5.
Submit your next manuscript to BioMed Central and take full advantage of:

- Convenient online submission

- Thorough peer review

- No space constraints or color figure charges

- Immediate publication on acceptance

- Inclusion in PubMed, CAS, Scopus and Google Scholar

- Research which is freely available for redistribution

Submit your manuscript at www.biomedcentral.com/submit
C Biomed Central 